\title{
General Tendencies in Semiotic Research
}

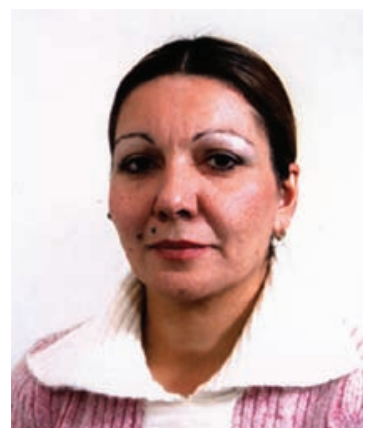

Diana Hambardzumyan

A t present many scholars deeply interested in semiotics are concerned with artistic literature, as it supplies with the necessary material for semiotic observations and theoretical conclusions. There are numerous investigations on the semiotics of Literature, accentuating on the point of view that Literature is one of the subjects of semiotic studies (see: Mukař ovsky, 1978; Todorov, 1983a, 355-369; Todorov, 1983b, 350-354; Khrapchenko, 1987, 278310; Barthes, 1988, 166-172; Nida, 1991). Literary semiotics is very much spoken about nowadays, presenting a lot of researches revealing the dubious problems of styling and creating images in Literature. The phrases "narrative semiotics", "literary semiotics", "semiotics of literature" are widely spread in them, though not yet being vividly defined, as to the scope of their global capacity. The Italian writer and scholar Umberto Eco is a very outstanding specialist in this sphere, whose concepts are considered to be the basis for clarifying the correlation between literary translation and semiotics.

Alongside with literary semiotics linguistic semiotics has also introduced its concepts of analyzing literary works paying great attention to the meaning of linguistic units, which, in our conscious are the reflection of various phenomena, activities and relationships existing in reality. A linguistic unit becomes a linguistic fact as soon as strong and historically, culturally correlated ties appear in between the linguistic unit as a sign and its referent.

E. Nida being one of the outstanding theorists in the sphere of linguistic semiotics, has introduced a lot of theoretical analyses concerning linguistics, semiotics, translation studies and literary criticism (see: Nida, 1964; Nida and Taber, 1969; Nida, 1991).

An artistic creation has always been perceived as the result of man's imagination and mind. As far as its final goal is concerned, it is its influence on the reader's selfsame mind and imagination. Through centuries writers have been inspired by this or that idea, theme, phenomenon, image, characteristic feature, which have become the basis of a literary work, supplying it with a unique structure. A literary work intends to influence on the reader's mind, imagination and feelings and all in all on the person's aesthetic comprehension. Everybody forms his/her concept of beauty through some concrete relationship (even through conflict and struggle) with beauty and ugliness, inasmuch as our ability of differentiating the essential from the subordinate, the exact from the bias, the right from the wrong, is realized on our way of searching for the Truth. The utmost purpose of Literature is the search of the truth, seeking for the beauty, which breeds the reader's aesthetic requirements. The reader's aesthetic taste is a many-lateral phenomenon, which a writer takes into consideration consciously or subconsciously, 
since he/she intends both to produce something corresponding to the reader's taste, as well as to brush up and develop the existing artistic criteria. In this process numerous codes emerge which are used to be called a code system. According to the simplest explanation of codes, which are either unanimously accepted or non-accepted symbols, they are nominative substitutes of this or that phenomenon or concept, subject or essence, material or abstraction.

It is striking to observe that the author's intention schemes the reader's comprehension. In this case the reader is guided by the system of images and the rich variety of meanings introduced into the artistic text. Reading and understanding an artistic creation is not a lineal activity at all. It predicts the reader's further conduct led by his/her comprehension. As a result of it the reader interprets the work, making numerous logical, analytical, synthetic commentaries, further on finding out and differentiating those implicit and explicit codes which contribute to his/her understanding of the author's intention and the aesthetic value of the work. The text which is introduced as a super-sign in semiotics, with its coded linguistic units is the only symbolic secret in between the author and the reader. The reader's purpose is to decode not only the smallest semiotic units, but to interpret the major tendency brought forth by the super-sign. Being a good reader is a thing, which the most outstanding writers of the world have declared to be their first consideration (W. Faulkner, J.L. Borges). So, reading and understanding literary works is, first and foremost, necessary for writers, linguists and literary critics, who, employing their global philological knowledge, may decode the codes of utmost mystery for common readers.

Language and linguistic units have been observed as sign systems by a number of Armenian and foreign scholars, among whom Professor Ed. Atayan with one of his basic linguistic works "The Inner Representation and Outer Reference of the Linguistic World" has become very prominent in our reality.

Linguistic sign is known to be a language and speech phenomenon. As it has got its subsigns, it is truly considered to be a microsystem of signs. If so, the super-sign, including various linguistic signs, in this case the literary text, is also examined as a sign system; the analysis of its subsigns and "inner signs" may greatly contribute to revealing the deepest sublayers of the original text.

A word, being a stylistic source, breeds a linguistic unit, as well as all the sublayers of a super-sign. On this occasion professor Ed. Atayan precisely defines the essence of a word as a means of comprising non-verbal objective reality in the man's socially subjective language world (see: Atayan, 1981: 79-80). If a linguistic sign has got a symbolic essence, it coincides with the aesthetic value existing in the sign. The matter is to reveal the non-verbal significance of a linguistic sign. The sign chain is endless: it starts from the linguistic sphere, goes through the real world and returns to language again. With the extension of sign boundaries non-signs are also included into it. Supersign or hyperseme is known as a unity of verbal and non-verbal signs.

It should be stated that the joint existence of the non-verbal world (the national culture, reality and environment reflected in the national literature, which is investigated by literary semiotics) and the linguistic world (the national language system and 
linguistic mentality, which is investigated by linguistic semiotics) comes to stipulate the progress of national literature.

As in case of every communication, the relationship between the artistic literature and its reader can be observed as a specific communication in between a speaker (essence) and a listener (phenomenon). Profoundly analyzing this relationship acad. Ed. Atayan comes to the conclusion that the above mentioned communication is a presentation satiated by stylistic stimules, the overwhelming instances of which, alongside with others, are the inner substance (content: speaker) and the outer form (expression: listener) (ibid. p. 166).

We think this "speaker" - "listener" bilateral unity, introduced by Ed. Atayan, becomes even more complicated when applied to literary translation. In this case the translator combines both the role of a "listener" and a "speaker". The translator uses his/her language knowledge and the content taken from the previous "speaker" (the author of the original) to insert it into a new outer form for a new verbal activity. This continual chain can be presented in the following diagram.

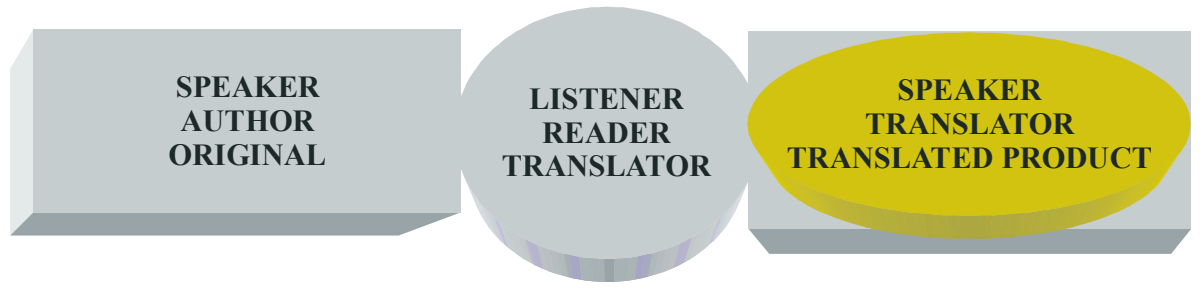

However, this chain can be transferred into another one, observing the same process from the semiotic point of view.
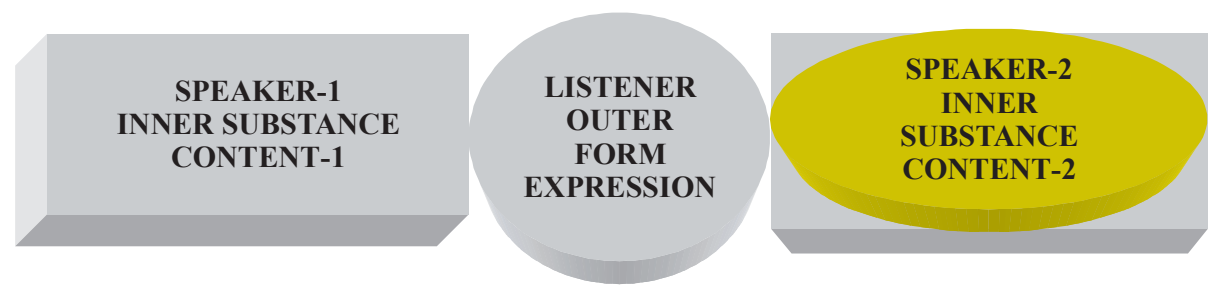

In this case "content- 1 " is both verbal and non-verbal essence, introducing the original, and "content-2" is the verbal and non-verbal essence of the translated product. According to the rules introduced in the extralinguistic system of signs, the most important problem for the investigator dealing with the translated product, is the examination of those extralinguistic phenomena, which have conditioned the global vertical context of the original. The latter is a complex phenomenon.

According to Gubbenette's definition, it includes the reader's pre-knowledge of the 
system of all social orders (the ideas, concepts, estimations, outlooks peculiar to them) enclosed in the author's works: (see: Гюььенет, 1991: 39). Katinenee adds the moral and aesthetic values typical of the era, that helps to understand the artistic intention and image system of the work (see: Катинене, 1983: 16).

Professor S. Zolyan has noticed that "the semiology of the second generation", which is apt to solve semantic problems, should overcome the shortcoming of the semiotic approach, i.e. it is only one-lateral investigation of the issue (see: Золян, 1991, 94-95). For about two and a half decades ago the semantic approach to language was a leading one in linguistics. Professor S. Zolyan confirms this fact referring to E. Benvenist's "General Linguistics" and observing the scholar's definition: "The semiotic (the sign) should be recognized, the semantic (the speech) should be understood", as a complete one, not needing any further interpretation (ibid. p.94).

Among the contemporary viewpoints T. Hawkes' concept appears to be vividly unique, though controversial (see: Hawkes, 1977). He insists on the fact that translation belongs to semiology, as far as the translation process "also includes a series of extralinguistic criteria". This surely restricts the boundaries of translation process including it into semiology, only giving more inportance to the extralinguistic criteria, ignoring the investigation of numerous linguistic and literary problems determined by the language material.

T. Nazarova has recently noticed that the semiology directed to the examination of verbal activity, aims to research it typologically, "dealing with narratology, logic, syntax and collocation" (see: Назарова, 2003: 191). As far as the semiology intending to investigate the structure of literary texts is concerned, it has been initially introduced by V. Prope, whose research works since the 50 s of the $20^{\text {th }}$ century have become the basis of investigating literary works from the angle of structuralism (ibid. p. 191). Today some scholars follow the principles of this investigation, sounding unanimous in dividing an artistic text into several parts and accentuating the existence of an a priori text.

\section{References:}

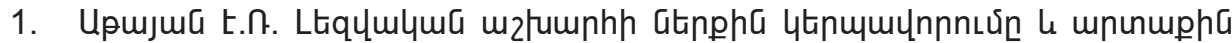

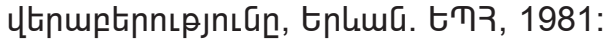

2. Гюььенет И.В. Основы филологической интерпретации литературнохудожественного текста. М.: МГУ, 1991.

3. Золян С.Т. Семантика и структура поэтического текста. Ереван: ЕГУ, 1991.

4. Катинене Н.Ф. Гловальный вертикальный контекст романов Т. Гарди, Автореф. ... канд. фил. наук, М., 1983.

5. Назарова Т.Б. Филология и семиотика (Современный английский язык). М.: Высшая школа, 2003.

6. Тодоров, Ц. Понятие литературы. // Семиотика. М., 1983, стр. 355-369, 186.

7. Тодоров, Ц. Семиотика литературы. // Семиотика. М., 1983, стр. 350-354.

8. Храпченко М.Б. Природа эстетического знака. // Познание литературы и 
искуства. М., 1987, стр. 278-310.

9. Barthes R. The Semiotic Challenge. New York, 1988.

10. Hawkes T. Structuralizm and Semiotics. Berkeley, 1977.

11. Mukař ovsky J. Structure, Sign and Function. New Haven, 1978.

12. Nida E.A. Towards a Science of Translating. Leiden, Holland, 1964.

13. Nida E.A. and Taber Ch. The Theory and Practice of Translation. Leiden, Holland, 1969.

14. Nida E.A. Signs, Sense, Translation. Bible Society, Capetown, 1991.

15. Todorov T. The Poetics of Prose. Ithaca, 1977.

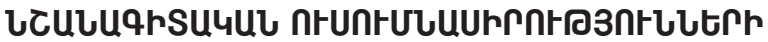 cunzulntr UhSกrUc}

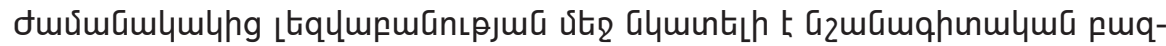

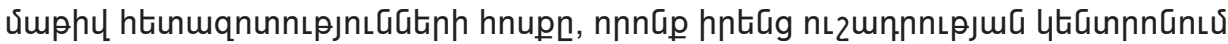

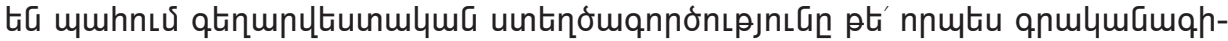

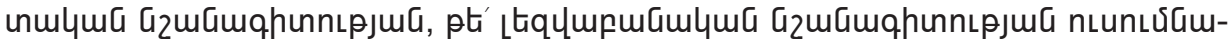

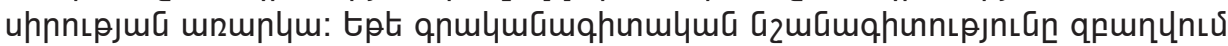

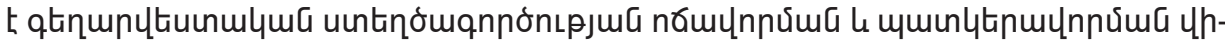

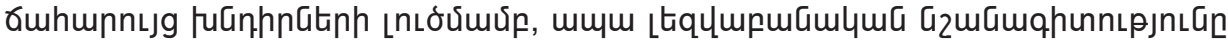

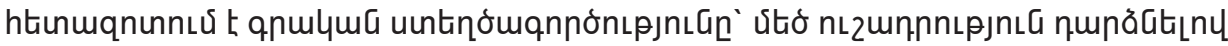

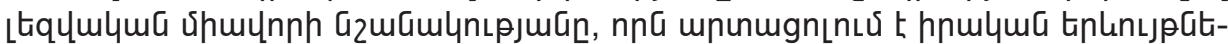

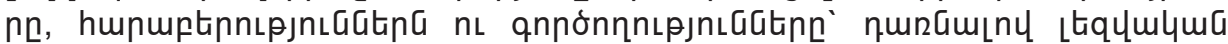

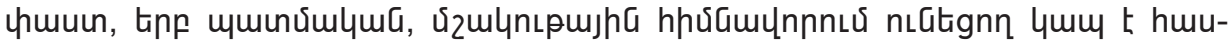

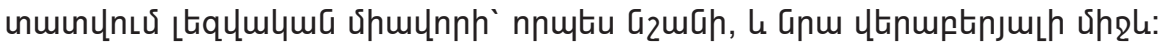

